\title{
Synthesis, Antiproliferative Effect, and Topoisomerase II Inhibitory Activity of 3-Methyl-2-phenyl-1H-indoles
}

Nace Zidar, Daniela Secci, Tihomir Tomašič, Lucija Peterlin Mašič, Danijel Kikelj, Daniele Passarella, Aida Nelly Garcia Argaez, Mariafrancesca Hyeraci, and Lisa Dalla Via*

Cite This: ACS Med. Chem. Lett. 2020, 11, 691-697

Read Online

ACCESS 1

Llll Metrics \& More

Article Recommendations

Supporting Information

ABSTRACT: A series of 3-methyl-2-phenyl- $1 H$-indoles was prepared and investigated for antiproliferative activity on three human tumor cell lines, HeLa, A2780, and MSTO-211H, and some structure-activity relationships were drawn up. The $\mathrm{GI}_{50}$ values of the most potent compounds (32 and 33) were lower than $5 \mu \mathrm{M}$ in all tested cell lines. For the most biologically relevant derivatives, the effect on human DNA topoisomerase II relaxation activity was investigated, which highlighted the good correlation between the antiproliferative effect and topoisomerase II inhibition. The most potent derivative, 32, was shown to induce the apoptosis pathway.

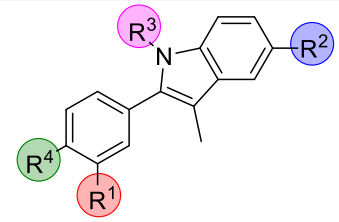

$\mathrm{R}^{1}$ and $\mathrm{R}^{2}=\mathrm{H}, \mathrm{OH}$ or $\mathrm{OCH}_{3}$ $\mathrm{R}^{3}=\mathrm{H}, \mathrm{CH}_{3}$, alkyl or phenoxyalkyl $\mathrm{R}^{4}=\mathrm{OH}, \mathrm{OCH}_{3}$ or arylcarboxyl

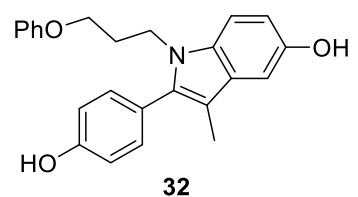

$\mathrm{GI}_{50}(\mathrm{HeLa})=4.4 \mu \mathrm{M}$

$\mathrm{GI}_{50}(\mathrm{~A} 2780)=2.2 \mu \mathrm{M}$

$\mathrm{GI}_{50}(\mathrm{MSTO}-211 \mathrm{H})=2.4 \mu \mathrm{M}$

Inhibitory effect on topo II relaxation Induction of apoptosis The obtained results highlight 3-methyl-2-phenyl-1H-indole as a promising scaffold for further optimization of compounds with potent antiproliferative and antitopoisomerase II activities.

KEYWORDS: 3-Methyl-2-phenyl-1H-indole, antiproliferative activity, topoisomerase II, apoptosis

$\mathrm{C}$ ancer is one of the leading causes of mortality worldwide, and its incidence is rapidly growing. ${ }^{1,2}$ The use of conventional chemotherapeutic agents, such as alkylating cytostatics, nucleoside analogues, anthracyclines, and compounds that stabilize microtubules is often limited because of their severe side effects. Drugs such as tyrosine kinase inhibitors and monoclonal antibodies that target specific signaling oncoproteins have been developed to increase specificity and thus to reduce side effects, but these can also have limitations, such as development of resistance. ${ }^{3}$ Despite the considerable progress made with new targeted therapies, for many patients the therapeutic options remain limited. Thus, new chemotherapeutics with improved pharmacotoxicological profiles are urgently needed. ${ }^{4}$

One of the important targets for anticancer drug discovery is human DNA topoisomerase II (topo II). ${ }^{3,5-9}$ Topoisomerases are enzymes that catalyze changes in DNA topology, and they are crucial for processes such as DNA replication and transcription and chromosomal segregation. They introduce transient breaks in the DNA molecule by cleaving one (type I topoisomerases) or both (type II topoisomerases) strands. ${ }^{10,11}$ Topo II is a type II topoisomerase, and two isoforms, $\alpha$ and $\beta$, are expressed in mammalian cells. Topo II $\beta$ is expressed constitutively throughout the cell cycle, whereas topo II $\alpha$ is predominantly in highly proliferating cells.

Based on their mechanism of action, compounds targeting topo II can be divided into two large groups: poisons ${ }^{12}$ and catalytic inhibitors. ${ }^{6,13-16}$ Topo II poisons stabilize the covalent DNA-topo II complex, leading to DNA damage and apoptotic cell death and are used in the clinic for the treatment of breast, lung, prostate, and hematological cancers and sarcomas. ${ }^{17}$ They included etoposide, doxorubicin, and mitoxantrone. A common side effect of DNA poisons is the risk of secondary malignancies and cardiotoxicity, which are mostly connected to the effects of these drugs on topo $\mathrm{II} \beta .^{18}$ On the other hand, catalytic inhibitors affect one of the steps in the catalytic cycle of the enzyme. In particular, they can block binding of the DNA molecule to the enzyme, compete for binding with ATP, inhibit cleavage of the DNA molecule, or prevent hydrolysis of ATP, ${ }^{12}$ and interestingly, they do not increase DNA cleavage, which could indicate an improved safety profile. ${ }^{5}$

We report here the design and synthesis of a series of 3methyl-2-phenyl- $1 H$-indole analogues with antiproliferative and topo II inhibitory effects (Figure 1A). The compounds were designed based on the 3-methyl-2-phenyl-1H-indole hit I (Figure 1A), which was identified through screening of an inhouse library of compounds against three selected human tumor cell lines: cervix adenocarcinoma (HeLa), ovarian carcinoma (A2780), and biphasic mesothelioma (MSTO$211 \mathrm{H})$. Compound I showed good antiproliferative activity,

Special Issue: In Memory of Maurizio Botta: His Vision of Medicinal Chemistry

Received: November 28, 2019

Accepted: January 24, 2020

Published: January 24, 2020

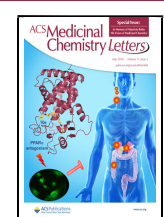


A

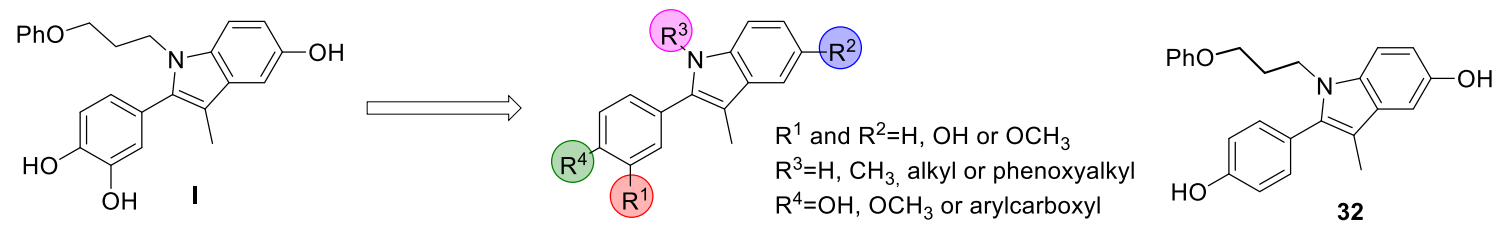

B<smiles></smiles>

Figure 1. Design of the 3-methyl-2-phenyl-1H-indoles as antiproliferative compounds, based on screening hit I (A); structures of flavonoids quercetin and luteolin with topo II inhibitory activities (B).

Scheme 1. Synthesis of Compounds $10-14^{a}$

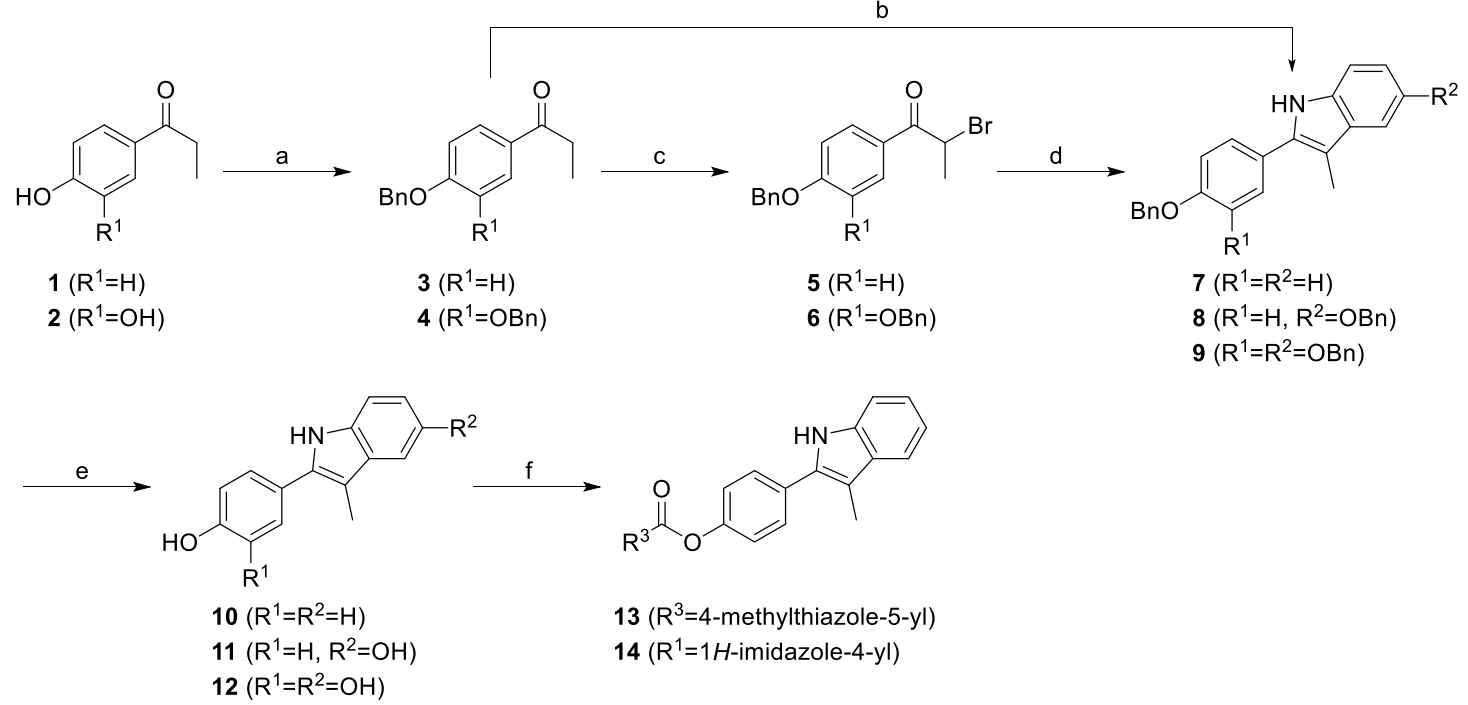

${ }^{a}$ Reagents and conditions: (a) benzyl bromide, $\mathrm{K}_{2} \mathrm{CO}_{3}$, acetone, reflux, $18 \mathrm{~h}$; (b) for 7: phenylhydrazine, $\mathrm{H}_{2} \mathrm{SO}_{4}$, acetone, reflux, $24 \mathrm{~h}$; (c) $\mathrm{Br}_{2}$, glacial acetic acid, $0{ }^{\circ} \mathrm{C}, 1 \mathrm{~h}$; (d) for 8, 9: 4-benzyloxyaniline·HCl, $\mathrm{Et}_{3} \mathrm{~N}, \mathrm{DMF}, 120{ }^{\circ} \mathrm{C}, 2 \mathrm{~h}$, then $150{ }^{\circ} \mathrm{C}, 3 \mathrm{~h}$; (e) $\mathrm{H}_{2}, 10 \% \mathrm{Pd} / \mathrm{C}, \mathrm{EtOH}, \mathrm{r.t}$., $18 \mathrm{~h}$; (f) for 13: 4-methylthiazole-5-carboxylic acid, EDC, 4-dimethylaminopyridine, $\mathrm{CH}_{2} \mathrm{Cl}_{2}$, r.t., 15 h; for 14: $1 \mathrm{H}$-imidazole-4-carboxylic acid, TBTU, NMM, DMF, r.t., 15 h.

with growth inhibition values $\left(\mathrm{GI}_{50}\right)$ in the micromolar range. Based on compound $\mathbf{I}$, a series of analogues was designed and synthesized, through varying the substituents on $\mathrm{R}^{1}-\mathrm{R}^{4}$ (Figure 1A). The antiproliferative activities of compounds were evaluated in vitro against $\mathrm{HeLa}, \mathrm{A} 2780$, and MSTO-211H cells. Because of structural similarities of our compounds with some naturally occurring flavonoids that inhibit topo II, such as quercetin and luteolin (Figure 1B), ${ }^{19-21}$ the topo II inhibitory effects of the most potent analogues were investigated. For compound 32, cytofluorimetric analysis was performed to investigate the mechanism of cell death.

The designed compounds were prepared according to synthetic pathways presented in Schemes 1 and 2. Full synthetic procedures and analytical data are available in the Supporting Information. The synthesis of the central indole scaffold started with benzyl protection of hydroxyl group(s) of propiophenones $\mathbf{1}$ and $\mathbf{2}$, to obtain ethers $\mathbf{3}$ and $\mathbf{4}$ (Scheme 1). These ethers were $\alpha$-brominated with bromine under acidic conditions, to yield 5 and 6 , which were then reacted with 4benzyloxyaniline in the Bischler-Möhlau indole synthesis, to give indoles 8-9. Indole 7 was obtained by Fischer indole synthesis from ketone 3 and phenylhydrazine under acidic conditions. Removal of the benzyl protecting groups of 7-9 to obtain phenols 10-12 was achieved by hydrogenation, using palladium on charcoal as catalyst. In addition, esters 13 and 14 were prepared from phenol 10: for 13, with 4-methylthiazole5-carboxylic acid using 1-ethyl-3-(3-(dimethylamino)propyl)carbodiimide (EDC) as coupling reagent, and for 14, from $1 \mathrm{H}$ imidazole-4-carboxylic acid using 2-(1H-benzotriazole-1-yl)1,1,3,3-tetramethylaminium tetrafluoroborate (TBTU). Moreover, the benzyl protected indoles 7-9 were reacted with different haloalkanes using $\mathrm{NaH}$ as the base in $N, N$ dimethylformamide (DMF), to give $N$-alkylated indoles 1525, which were deprotected by catalytic hydrogenation to obtain the final compounds 26, 27, and 29-37 (Scheme 2). Carboxylic acid derivative $\mathbf{2 8}$ was obtained by alkaline hydrolysis of ester 27. In addition, methylation of 37 with methyl iodide in the presence of cesium carbonate gave ether 38. 
Scheme 2. Synthesis of Compounds $26-38^{a}$

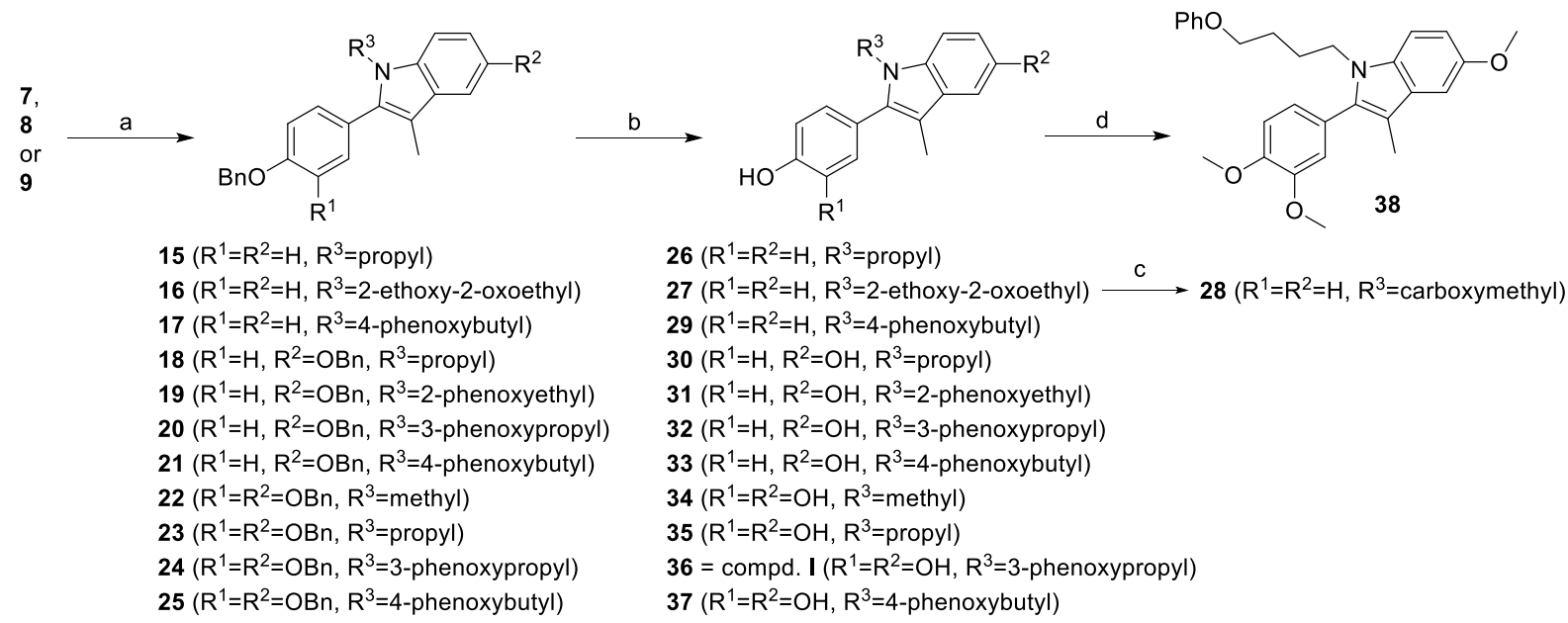

${ }^{a}$ Reagents and conditions: (a) for 15, 18, 23: 1-bromopropane; for 16: ethyl bromoacetate; for 17, 21, 25: (4-bromobutoxy)benzene; for 20, 24: (3-bromopropoxy)benzene; for 19: (2-bromoethoxy)benzene; for 22: methyl iodide; $\mathrm{NaH}$, DMF, r.t., $3 \mathrm{~h}$; (b) $\mathrm{H}_{2}, 10 \% \mathrm{Pd} / \mathrm{C}, \mathrm{THF} / \mathrm{EtOH}$, r.t., 18 h; (c) $1 \mathrm{M} \mathrm{NaOH}$; (d) methyl iodide, $\mathrm{Cs}_{2} \mathrm{CO}_{3}$, acetone, $60{ }^{\circ} \mathrm{C}$, $48 \mathrm{~h}$.

The antiproliferative effect exerted by the new compounds 10-14 and 26-38 and by the well-known inhibitors of topo II $m$-amsacrine ( $m$-AMSA) and quercetin was assayed on three human tumor cell lines: HeLa, A2780, and MSTO-211H. The results are expressed as $\mathrm{GI}_{50}$ values, i.e. the concentration $(\mu \mathrm{M})$ of compound able to inhibit the growth in $50 \%$ of cells with respect to a control culture. The obtained data are shown in Table 1.

Most of the tested compounds had significant antiproliferative effect on the selected cell lines, showing $\mathrm{GI}_{50}$ values ranging from 2.0 to $18 \mu \mathrm{M}$. In general, the analogues 10-14, with the unsubstituted $\mathrm{R}^{3}\left(\mathrm{R}^{3}=\mathrm{H}\right)$, showed a rather low antiproliferative effect. Nevertheless, their $\mathrm{GI}_{50}$ values allowed us to draw some preliminary structure-activity relationships. In particular, it can be seen that $\mathbf{1 0}$ (unsubstituted at $\mathrm{R}^{1}$ and $\mathrm{R}^{2}$; hydroxyl group at $\mathrm{R}^{4}$ ) did not have any effect at the tested concentrations. The introduction of a hydroxyl group at $\mathrm{R}^{2}$ (11) induced a small increase in antiproliferative activity against HeLa and A2780 cells, while the insertion of a hydroxyl group at both $R^{1}$ and $R^{2}(12)$ resulted in a $G_{50}$ value of 2.2 $\mu \mathrm{M}$ on A2780 cells. Finally, the data obtained for compounds 13 and 14 suggest that large arylcarboxy substituents at $R^{4}$ do not improve the cell effect.

As regards compounds 26-38, characterized by alkyl substituents at $\mathrm{R}^{3}$, they appeared generally more potent than 10-14. This can be seen by comparing the cell growth inhibition data of $10\left(\mathrm{GI}_{50}>20 \mu \mathrm{M}\right.$, on all tested cell lines) with those of 26, 27, and 29. Interestingly, 28 with a carboxymethylene substituent at $\mathrm{R}^{3}$ was not active $\left(\mathrm{GI}_{50}>20\right.$ $\mu \mathrm{M}$ ), which indicated that introduction of groups with low $\mathrm{p} K_{a}$ is detrimental for cellular activity. Similarly as for 10, 26, 27, and 29, also the activity of $\mathbf{1 2}\left(\mathrm{R}^{1}, \mathrm{R}^{2}\right.$, and $\left.\mathrm{R}^{4}=\mathrm{OH}\right)$ on HeLa and MSTO- $211 \mathrm{H}$ cells increased when alkyl substituents were introduced at $\mathrm{R}^{3}\left(12, \mathrm{GI}_{50}>20 \mu \mathrm{M} ; 34-37, \mathrm{GI}_{50}\right.$ from 3.4 to $18 \mu \mathrm{M})$. On the other hand, the activity of 12 on A2780 cells $\left(\mathrm{GI}_{50}=2.2 \mu \mathrm{M}\right)$ was higher compared to that of 34 (methyl group at $\mathrm{R}^{3} ; \mathrm{GI}_{50}=14 \mu \mathrm{M}$ ), 35 (propyl group at $\mathrm{R}^{3} ; \mathrm{GI}_{50}=8.4$ $\mu \mathrm{M}$ ), 36 (phenoxypropyl group at $\mathrm{R}^{3} ; \mathrm{GI}_{50}=7.4 \mu \mathrm{M}$ ), and 37 (phenoxybutyl group at $\mathrm{R}^{3} ; \mathrm{GI}_{50}=4.3 \mu \mathrm{M}$ ).

The compounds with a hydroxyl group at $\mathrm{R}^{2}(11,12,30-$ 37 ) were generally more potent than those with unsubstituted
$\mathrm{R}^{2}(10,13,26-29)$, as demonstrated by the comparison between 26 (unsubstituted $\mathrm{R}^{2}$ ) and 30 (hydroxyl group at $\mathrm{R}^{2}$ ). A similar behavior can also be observed for 29 (unsubstituted $R^{2}$ ) with respect to 33 , even if the differences in $\mathrm{GI}_{50}$ values appeared notably reduced.

The presence of an $\mathrm{OH}$ group at $\mathrm{R}^{1}$ had unfavorable effects on the antiproliferative activity as demonstrated by the higher potencies of $30\left(\mathrm{R}^{1}=\mathrm{H}\right)$ versus $35\left(\mathrm{R}^{1}=\mathrm{OH}\right), 32\left(\mathrm{R}^{1}=\mathrm{H}\right)$ versus $36\left(\mathrm{R}^{1}=\mathrm{OH}\right)$, and $33\left(\mathrm{R}^{1}=\mathrm{H}\right)$ versus $37\left(\mathrm{R}^{1}=\mathrm{OH}\right)$. The good antiproliferative profile of $30\left(\mathrm{GI}_{50}=7.9 \mu \mathrm{M}, 2.3\right.$ $\mu \mathrm{M}$ and $2.9 \mu \mathrm{M}$ for HeLa, A2780 and MSTO-211H, respectively) was further improved by the addition of a phenoxy group to the propyl side chain of $\mathrm{R}^{3}$, to obtain the 3phenoxypropyl derivative 32 . Promising activity was maintained even when the length of the alkyl linker was increased from propylene to butylene, as for 33 . The $\mathrm{GI}_{50}$ values of 32 and 33 were in the low micromolar range for all cell lines tested, and these values were the lowest among all of the studied analogues, thus highlighting $\mathbf{3 2}$ and 33 as the most promising compounds of the series. The comparison between the antiproliferative activities of 32 (3-phenoxypropyl substituent at $\mathrm{R}^{3}$ ) and 31 (3-phenoxyethyl substituent at $\mathrm{R}^{3}$ ) showed a significant decrease in activity for the latter in all tested cell lines. This result indicates that the appropriate length of the side chain at $\mathrm{R}^{3}$ is crucial for the biological effects.

Finally, alkylation of the hydroxyl groups of 37 to obtain the trimethoxy derivative $\mathbf{3 8}$ resulted in a significant decrease in the antiproliferative effect, which indicates the possibility of hydrogen bonding between the $\mathrm{OH}$ groups and the biological target.

Based on the structural similarities of the prepared compounds with some flavonoid inhibitors of topo II (Figure 1B) and with the aim to investigate the molecular mechanism responsible for the antiproliferative activity, we evaluated the effect of the most interesting analogues on the relaxation of supercoiled plasmid DNA catalyzed by topo II. $^{22,23}$

In the series of compounds with unsubstituted $\mathrm{R}^{3}$ (10-14), the activities of the most potent derivatives, 11 and 12 , were analyzed and $m$-AMSA (Figure 2 ) and quercetin (Figure $1 \mathrm{SI}$ ) were used as references. 
Table 1. Chemical Structures and Cell Growth Inhibition in the Presence of Compounds 10-14 and 26-38 and of $m$-AMSA and Quercetin as Reference

\begin{tabular}{|c|c|c|c|c|c|c|c|}
\hline Compd. & $\mathrm{R}^{1}$ & $\mathrm{R}^{2}$ & $\mathrm{R}^{3}$ & $\mathrm{R}^{4}$ & $\mathrm{HeLa}$ & A 2780 & $\begin{array}{c}\text { MSTO- } \\
211 \mathrm{H}\end{array}$ \\
\hline 10 & $\mathrm{H}$ & $\mathrm{H}$ & $\mathrm{H}$ & $\mathrm{OH}$ & $>20$ & $>20$ & $>20$ \\
\hline 11 & $\mathrm{H}$ & $\mathrm{OH}$ & $\mathrm{H}$ & $\mathrm{OH}$ & $16 \pm 2$ & $11 \pm 2$ & $>20$ \\
\hline 12 & $\mathrm{OH}$ & $\mathrm{OH}$ & $\mathrm{H}$ & $\mathrm{OH}$ & $>20$ & $2.2 \pm 0.5$ & $>20$ \\
\hline 13 & $\mathrm{H}$ & $\mathrm{H}$ & $\mathrm{H}$ & & $>20$ & $13 \pm 1$ & $>20$ \\
\hline 14 & $\mathrm{H}$ & $\mathrm{H}$ & $\mathrm{H}$ & o & $>20$ & $>20$ & $>20$ \\
\hline 26 & $\mathrm{H}$ & $\mathrm{H}$ & $\mathrm{CH}_{2} \mathrm{CH}_{2} \mathrm{CH}_{3}$ & $\mathrm{OH}$ & $>20$ & $9.0 \pm 2.2$ & $7.1 \pm 1.4$ \\
\hline 27 & $\mathrm{H}$ & $\mathrm{H}$ & $\mathrm{CH}_{2} \mathrm{COOCH}_{2} \mathrm{CH}_{3}$ & $\mathrm{OH}$ & $>20$ & $13 \pm 1$ & $>20$ \\
\hline 28 & $\mathrm{H}$ & $\mathrm{H}$ & $\mathrm{CH}_{2} \mathrm{COOH}$ & $\mathrm{OH}$ & $>20$ & $>20$ & $>20$ \\
\hline 29 & $\mathrm{H}$ & $\mathrm{H}$ & $\mathrm{CH}_{2} \mathrm{CH}_{2} \mathrm{CH}_{2} \mathrm{CH}_{2} \mathrm{OPh}$ & $\mathrm{OH}$ & $11 \pm 2$ & $3.1 \pm 0.6$ & $3.3 \pm 0.5$ \\
\hline 30 & $\mathrm{H}$ & $\mathrm{OH}$ & $\mathrm{CH}_{2} \mathrm{CH}_{2} \mathrm{CH}_{3}$ & $\mathrm{OH}$ & $7.9 \pm 1.9$ & $2.3 \pm 0.6$ & $2.9 \pm 0.8$ \\
\hline 31 & $\mathrm{H}$ & $\mathrm{OH}$ & $\mathrm{CH}_{2} \mathrm{CH}_{2} \mathrm{OPh}$ & $\mathrm{OH}$ & $15 \pm 0.3$ & $4.7 \pm 0.9$ & $7.6 \pm 1.2$ \\
\hline 32 & $\mathrm{H}$ & $\mathrm{OH}$ & $\mathrm{CH}_{2} \mathrm{CH}_{2} \mathrm{CH}_{2} \mathrm{OPh}$ & $\mathrm{OH}$ & $4.4 \pm 1.0$ & $2.2 \pm 0.4$ & $2.4 \pm 0.4$ \\
\hline 33 & $\mathrm{H}$ & $\mathrm{OH}$ & $\mathrm{CH}_{2} \mathrm{CH}_{2} \mathrm{CH}_{2} \mathrm{CH}_{2} \mathrm{OPh}$ & $\mathrm{OH}$ & $4.0 \pm 0.6$ & $2.0 \pm 0.6$ & $2.9 \pm 0.2$ \\
\hline 34 & $\mathrm{OH}$ & $\mathrm{OH}$ & $\mathrm{CH}_{3}$ & $\mathrm{OH}$ & $>20$ & $14 \pm 3$ & $>20$ \\
\hline 35 & $\mathrm{OH}$ & $\mathrm{OH}$ & $\mathrm{CH}_{2} \mathrm{CH}_{2} \mathrm{CH}_{3}$ & $\mathrm{OH}$ & $>20$ & $8.4 \pm 1.3$ & $>20$ \\
\hline $36^{b}$ & $\mathrm{OH}$ & $\mathrm{OH}$ & $\mathrm{CH}_{2} \mathrm{CH}_{2} \mathrm{CH}_{2} \mathrm{OPh}$ & $\mathrm{OH}$ & $18 \pm 1$ & $7.4 \pm 0.7$ & $7.1 \pm 1.2$ \\
\hline 37 & $\mathrm{OH}$ & $\mathrm{OH}$ & $\mathrm{CH}_{2} \mathrm{CH}_{2} \mathrm{CH}_{2} \mathrm{CH}_{2} \mathrm{OPh}$ & $\mathrm{OH}$ & $10 \pm 1$ & $4.3 \pm 1.3$ & $3.4 \pm 0.9$ \\
\hline 38 & $\mathrm{OCH}_{3}$ & $\mathrm{OCH}_{3}$ & $\mathrm{CH}_{2} \mathrm{CH}_{2} \mathrm{CH}_{2} \mathrm{CH}_{2} \mathrm{OPh}$ & $\mathrm{OCH}_{3}$ & $>20$ & $17 \pm 4$ & $13 \pm 2$ \\
\hline$m$-AMSA ${ }^{c}$ & & & & & $0.031 \pm 0.016$ & $0.027 \pm 0.005$ & $0.019 \pm 0.001$ \\
\hline \multicolumn{4}{|c|}{ Quercetin $^{\mathrm{c}}$} & & $17.7 \pm 0.9$ & $19.7 \pm 2.0$ & $>20$ \\
\hline
\end{tabular}

${ }^{a}$ Values are the mean $\pm \mathrm{SD}$ of at least three independent experiments. ${ }^{b}$ Compound $\mathrm{I} .{ }^{c}$ Reference compounds.

Both 11 and 12 are able to inhibit topo II relaxation activity at $100 \mu \mathrm{M}$ concentration (Figure $2 \mathrm{~A}$ ). In detail, compound $\mathbf{1 2}$ showed an electrophoretic pattern with almost solely supercoiled DNA, which suggests that it completely inhibited topo II activity. For compound 11, as well as the presence of supercoiled DNA, some topoisomers were formed, thus suggesting a slightly lower inhibitory activity. To further confirm these effects, topo II was incubated in the presence of 11 and 12 at $25 \mu \mathrm{M}$ and $50 \mu \mathrm{M}$ (Figure 2B). At the lower concentration, only 12 inhibited the activity of topo II, while 11 had no measurable effect. Interestingly, these results correlate with the antiproliferative effects on A2780 cells, where 11 showed a $\mathrm{GI}_{50}$ value $\left(\mathrm{GI}_{50}=11 \mu \mathrm{M}\right)$ about 5 times higher with respect to $12\left(\mathrm{GI}_{50}=2.2 \mu \mathrm{M}\right)$ (Table 1$)$.

As regards the compounds having alkyl substituents at the $\mathrm{R}^{3}$ position (26-38), the effects on topo II activity of $100 \mu \mathrm{M}$ 26-29 (unsubstituted at $\mathrm{R}^{1}$ and $\mathrm{R}^{2}$ ) are shown in Figure 3. For 26-28, the electrophoretic patterns appeared comparable to that of topo II alone, with a series of topoisomers as a result of the enzyme relaxation activity. On the other hand, as well as a weak formation of topoisomers, in the presence of 29, a strong band corresponding to supercoiled DNA also appears, indicative of an inhibitory effect, and in agreement with the antiproliferative data shown in Table 1. 


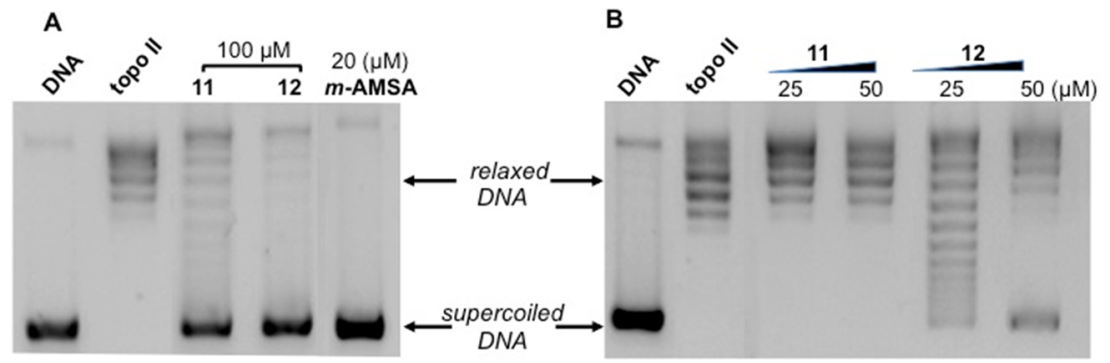

Figure 2. Effect of compounds 11 and 12 on relaxation of supercoiled pBR322 DNA by human recombinant topoisomerase II. Supercoiled DNA (DNA) was incubated with the enzyme in the absence (topo II) and in the presence of 11 and 12 at $100 \mu \mathrm{M}(\mathbf{A})$ or $25 \mu \mathrm{M}$ and $50 \mu \mathrm{M}(\mathbf{B})$. Twenty $\mu \mathrm{M} m$-AMSA was used as reference.

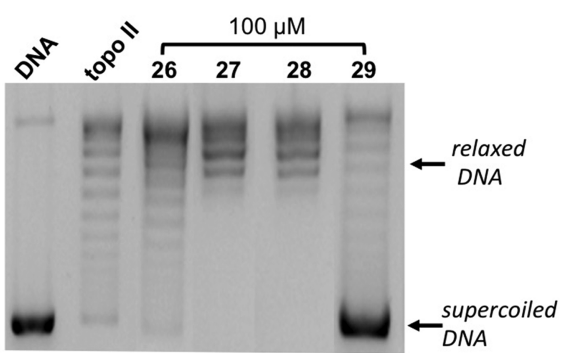

Figure 3. Effect of compounds $26-29$ on relaxation of supercoiled pBR322 DNA by human recombinant topoisomerase II. Supercoiled DNA (DNA) was incubated with topo II in the absence (topo II) and in the presence of $26-29$ at $100 \mu \mathrm{M}$.

Compounds 30-33 (hydroxyl substituent at $\mathrm{R}^{2}$ ) were characterized by low micromolar $\mathrm{GI}_{50}$ values (Table 1 ), and actually they showed significant topo II inhibitory activity at $100 \mu \mathrm{M}$ concentration (Figure 4A). In particular, in these experimental conditions, for 30, 32, and 33 a marked band of supercoiled DNA was observed. For 31, a slightly lower inhibitory activity was detected, in agreement with its lower antiproliferative effect with respect to $\mathbf{3 0 , 3 2}$, and $\mathbf{3 3}$ (Table 1). In addition, incubation of the enzyme with $25 \mu \mathrm{M}$ and $50 \mu \mathrm{M}$ concentrations (Figure 4B) highlighted $\mathbf{3 2}$ as the most effective and 31 as the least effective of this group of compounds. Indeed, in the presence of 32 a complete block of DNA relaxation can be observed at $50 \mu \mathrm{M}$, while no effect was obtained in the presence of $\mathbf{3 1}$ at the same concentration.

Finally, topo II inhibition by 34-38, which showed intermediate antiproliferative profiles, was also investigated (Figure 5). Incubation of topo II in the presence of $100 \mu \mathrm{M}$ 34-38 indicates compounds 34 and $\mathbf{3 8}$ as the less active derivatives of this series, in agreement with their relatively low antiproliferative effect, while a more pronounced inhibitory

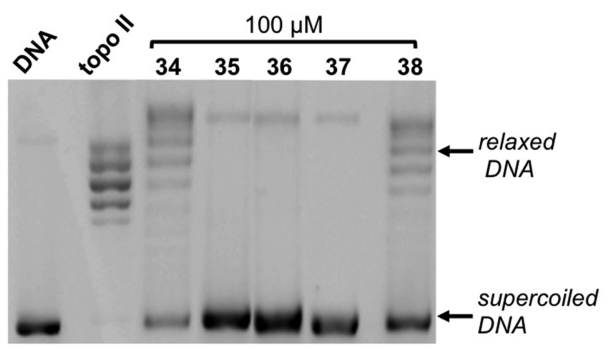

Figure 5. Effect of compounds $34-38$ on the relaxation of supercoiled pBR322 DNA by human recombinant topoisomerase II. Supercoiled DNA (DNA) was incubated with topo II in the absence (topo II) and in the presence of 34-38 at $100 \mu \mathrm{M}$.

activity is exerted by 35-37, according with their more significant inhibition of cell proliferation (Figure 5; Table 1).

The interesting biological profile of 32 prompted us to investigate more in depth its effects on cells, and in particular the mechanism involved in cell death. For this purpose, the most sensitive A2780 cells were treated with increasing concentrations of 32, incubated with the fluorescent probe JC-1, and then analyzed by flow cytometry, as previously described. $^{24}$ The green monomeric fluorescent dye JC-1 accumulates in the mitochondrial matrix driven by the membrane potential, negative inside. This uptake leads to an increase in JC-1 concentration in mitochondria that promotes the formation of aggregates, which are characterized by high red fluorescence. The activation of the apoptosis pathway can result in collapse of mitochondrial transmembrane potential and release of mitochondrial proapoptotic factors in the cytoplasm. This collapse allows the leakage of JC-1, with a consequent decrease in red fluorescence. Figure 6 shows that A2780 cells incubated in the presence of 32 underwent a concentration-dependent decrease of mitochondrial trans-

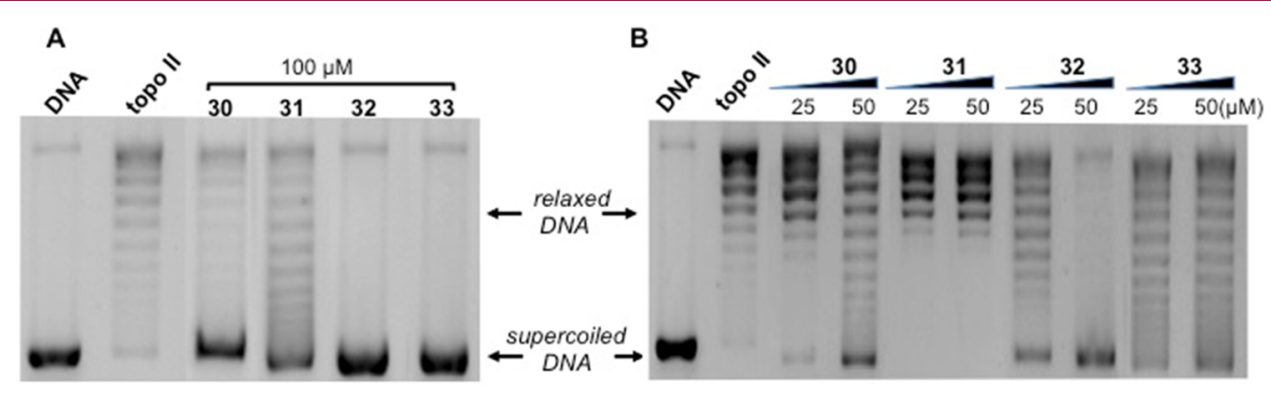

Figure 4. Effect of compounds 30-33 on the relaxation of supercoiled pBR322 DNA by human recombinant topoisomerase II. Supercoiled DNA (DNA) was incubated with topo II in the absence (topo II) and in the presence of 30-33 at $100 \mu \mathrm{M}$ (A), or at $25 \mu \mathrm{M}$ and $50 \mu \mathrm{M}$ (B). 

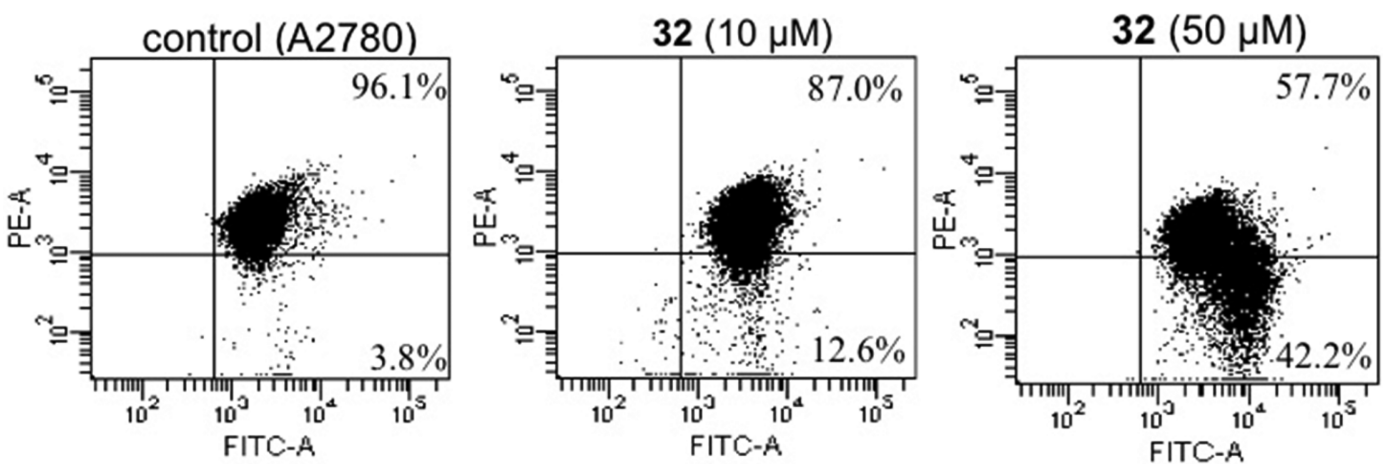

Figure 6. Mitochondrial membrane potential assessed by flow cytometry in A2780 cells after JC-1 staining. Cells were incubated for $28 \mathrm{~h}$ in the absence (control) and in the presence of compound 32 at the indicated concentrations. The percentages of cells with polarized (above) and depolarized (below) mitochondrial membranes are shown.

membrane potential, with about $40 \%$ of cells showing depolarized mitochondria at $50 \mu \mathrm{M}$ concentration.

The ability of $\mathbf{3 2}$ to induce apoptosis was further confirmed by the analysis of hypodiploid cells stained with propidium iodide. Indeed, an important hallmark of apoptosis is the activation of endonucleases that cleave DNA at internucleosomal sites, thus creating a large number of small fragments of nucleic acid. Then, on DNA content histograms, apoptotic cells show DNA content as sub- $\mathrm{G}_{0}$ or hypodiploid peak. ${ }^{25,26}$

Figure 7 shows the results obtained in A2780 cells incubated with $10 \mu \mathrm{M}$ and $50 \mu \mathrm{M} 32$, stained with propidium iodide and

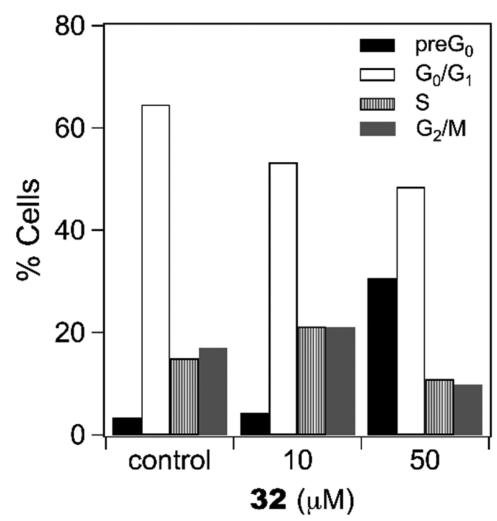

Figure 7. Flow cytometry analysis of A2780 cells treated for $28 \mathrm{~h}$ with compound 32 at the indicated concentrations and stained with propidium iodide.

analyzed for DNA/cell content. Compound 32 induced a significant increase in the sub- $\mathrm{G}_{0}$ phase, thus indicating apoptotic events in about $30 \%$ of cells treated with the higher concentration (Figure 7).

A series of 3-methyl-2-phenyl- $1 H$-indoles (10-14 and 2638) was prepared and evaluated for the antiproliferative effect on three human tumor cell lines, HeLa, A2780, and MSTO$211 \mathrm{H}$. The role of different substituents on the two aromatic moieties of these compounds was discussed. In particular, compounds with an unsubstituted $\mathrm{R}^{1}$ were generally more potent than those with a hydroxyl or a methoxy group at $\mathrm{R}^{1}$. On the other hand, at $\mathrm{R}^{2}$ and $\mathrm{R}^{4}$, hydroxyl groups were generally preferred. The most active compounds contained alkyl or phenoxyalkyl substituents at $\mathrm{R}^{3}$, with the size of these substituents important for the activity. The most interesting compound was 32 , showing $\mathrm{GI}_{50}$ values of $4.4 \mu \mathrm{M}, 2.2 \mu \mathrm{M}$, and $2.4 \mu \mathrm{M}$ on HeLa, A2780, and MSTO-211H cell lines, respectively. Notably, for six compounds (12, 29-31, 33, 37), $\mathrm{GI}_{50}$ values lower than $5 \mu \mathrm{M}$ against at least one cell line were obtained.

For selected compounds $(11,12,26-38)$, the effect on the relaxation of supercoiled plasmid DNA catalyzed by topo II was also measured. The obtained results highlighted a good correlation between the inhibition of enzyme and the antiproliferative effect. For the most promising compound 32, cytofluorimetric analysis showed the ability to induce a concentration-dependent collapse of mitochondrial transmembrane potential. Moreover, a significant increase in the sub- $G_{0}$ phase was measured in cells incubated with 32, confirming the occurrence of apoptosis. Overall, these data highlight 3-methyl-2-phenyl- $1 H$-indole as a promising scaffold for the design of compounds with significant antiproliferative and antitopo II activities and provide new ideas for further optimization.

\section{ASSOCIATED CONTENT}

\section{SI Supporting Information}

The Supporting Information is available free of charge at https://pubs.acs.org/doi/10.1021/acsmedchemlett.9b00557.

General information-chemistry; synthetic procedures and analytical data; ${ }^{1} \mathrm{H}$ and ${ }^{13} \mathrm{C}$ spectra of representative compounds; materials and methods-biological studies; Figure 1 SI: Effect of quercetin on the relaxation of supercoiled pBR322 DNA by human recombinant topoisomerase II (topo II); references (PDF)

\section{AUTHOR INFORMATION}

\section{Corresponding Author}

Lisa Dalla Via - Department of Pharmaceutical and

Pharmacological Sciences, University of Padova, I-35131

Padova, Italy; ○ orcid.org/0000-0002-9828-9388;

Phone: +39-049-8275712; Email: lisa.dallavia@unipd.it

\section{Authors}

Nace Zidar - Faculty of Pharmacy, University of Ljubljana, 1000 Ljubljana, Slovenia; (1) orcid.org/0000-0003-19050158

Daniela Secci - Faculty of Pharmacy, University of Ljubljana, 1000 Ljubljana, Slovenia

Tihomir Tomašic - Faculty of Pharmacy, University of Ljubljana, 1000 Ljubljana, Slovenia; 이이이.org/0000-00015534-209X 
Lucija Peterlin Mašič - Faculty of Pharmacy, University of Ljubljana, 1000 Ljubljana, Slovenia

Danijel Kikelj - Faculty of Pharmacy, University of Ljubljana, 1000 Ljubljana, Slovenia

Daniele Passarella - Department of Chemistry, University of Milan, 20133 Milan, Italy

Aida Nelly Garcia Argaez - Department of Pharmaceutical and Pharmacological Sciences, University of Padova, I-35131 Padova, Italy

Mariafrancesca Hyeraci - Department of Pharmaceutical and Pharmacological Sciences, University of Padova, I-35131 Padova, Italy

Complete contact information is available at:

https://pubs.acs.org/10.1021/acsmedchemlett.9b00557

\section{Author Contributions}

The manuscript was written using contributions from all authors. All authors have given approval to the final version of the manuscript.

\section{Notes}

The authors declare no competing financial interest.

\section{ACKNOWLEDGMENTS}

This work was supported by the Slovenian Research Agency (Grant No. P1-0208) and by Italian MIUR (Ministero dell'Istruzione, dell'Università e della Ricerca). The authors thank Žiga Hodnik for the help with chemical synthesis and Dušan Zigon (Mass Spectrometry Center, Jožef Stefan Institute, Ljubljana, Slovenia) for recording mass spectra.

\section{ABBREVIATIONS}

DMF, N,N-dimethylformamide; DIAD, diisopropylazodicarboxylate; DMSO, dimethyl sulfoxide; EDC, 1-ethyl-3-(3(dimethylamino)propyl)carbodiimide; EDTA, ethylenediaminetetraacetic acid; m-AMSA, meta-amsacrine; NMM, $N$ methylmorpholine; TBTU, O-(benzotriazol-1-yl)- $N, N, N^{\prime}, N^{\prime}$ tetramethyluronium tetrafluoroborate; THF, tetrahydrofuran; topo II, human DNA topoisomerase II

\section{REFERENCES}

(1) World Cancer Report 2014; Stewart, B.W., Wild, C.P., Eds.; WHO, 2014.

(2) Bray, F.; Ferlay, J.; Soerjomataram, I.; Siegel, R. L.; Torre, L. A.; Jemal, A. Global cancer statistics 2018: GLOBOCAN estimates of incidence and mortality worldwide for 36 cancers in 185 countries. Ca-Cancer J. Clin. 2018, 68 (6), 394-424.

(3) Dang, C. V.; Reddy, E. P.; Shokat, K. M.; Soucek, L. Drugging the 'undruggable' cancer targets. Nat. Rev. Cancer 2017, 17, 502-508.

(4) Hoelder, S.; Clarke, P. A.; Workman, P. Discovery of small molecule cancer drugs: successes, challenges and opportunities. Mol. Oncol. 2012, 6 (2), 155-176.

(5) Nitiss, J. L. Targeting DNA topoisomerase II in cancer chemotherapy. Nat. Rev. Cancer 2009, 9 (5), 338-350.

(6) Pommier, Y. Drugging topoisomerases: lessons and challenges. ACS Chem. Biol. 2013, 8 (1), 82-95.

(7) Liang, X. X.; Wu, Q.; Luan, S. X.; Yin, Z. Q.; He, C. L.; Yin, L. Z.; Zou, Y. F.; Yuan, Z. X.; Li, L. X.; Song, X.; He, M.; Lv, C.; Zhang, W. A comprehensive review of topoisomerase inhibitors as anticancer agents in the past decade. Eur. J. Med. Chem. 2019, 171, 129-168.

(8) Delgado, J. L.; Hsieh, C. M.; Chan, N. L.; Hiasa, H. Topoisomerases as anticancer targets. Biochem. J. 2018, 475 (2), 373-398.
(9) Hevener, K. E.; Verstak, T. A.; Lutat, K. E.; Riggsbee, D. L.; Mooney, J. W. Recent developments in topoisomerase-targeted cancer chemotherapy. Acta Pharm. Sin. B 2018, 8 (6), 844-861.

(10) Champoux, J. J. DNA topoisomerases: structure, function, and mechanism. Annu. Rev. Biochem. 2001, 70, 369-413.

(11) Parker, M. W.; Botchan, M. R.; Berger, J. M. Mechanisms and regulation of DNA replication initiation in eukaryotes. Crit. Rev. Biochem. Mol. Biol. 2017, 52 (2), 107-144.

(12) Pogorelčnik, B.; Perdih, A.; Solmajer, T. Recent developments of DNA poisons - human DNA topoisomerase II alpha inhibitors - as anticancer agents. Curr. Pharm. Des. 2013, 19 (13), 2474-2488.

(13) Khadka, D. B.; Cho, W. J. Topoisomerase inhibitors as anticancer agents: a patent update. Expert Opin. Ther. Pat. 2013, 23 (8), 1033-1056.

(14) Chene, P.; Rudloff, J.; Schoepfer, J.; Furet, P.; Meier, P.; Qian, Z.; Schlaeppi, J. M.; Schmitz, R.; Radimerski, T. Catalytic inhibition of topoisomerase II by a novel rationally designed ATP-competitive purine analogue. BMC Chem. Biol. 2009, 9, 1.

(15) Pogorelčnik, B.; Brvar, M.; Zegura, B.; Filipič, M.; Solmajer, T.; Perdih, A. Discovery of mono- and disubstituted $1 H$-pyrazolo[3,4]pyrimidines and $9 \mathrm{H}$-purines as catalytic inhibitors of human DNA topoisomerase IIalpha. ChemMedChem 2015, 10 (2), 345-359.

(16) Janežič, M.; Pogorelčnik, B.; Brvar, M.; Solmajer, T.; Perdih, A. 3 -substituted- $1 \mathrm{H}$-indazoles as catalytic inhibitors of the human DNA topoisomerase II alpha. ChemistrySelect 2017, 2 (1), 480-488.

(17) Jensen, L. H.; Thougaard, A. V.; Grauslund, M.; Sokilde, B.; Carstensen, E. V.; Dvinge, H. K.; Scudiero, D. A.; Jensen, P. B.; Shoemaker, R. H.; Sehested, M. Substituted purine analogues define a novel structural class of catalytic topoisomerase II inhibitors. Cancer Res. 2005, 65 (16), 7470-7477.

(18) Pogorelčnik, B.; Brvar, M.; Zajc, I.; Filipič, M.; Solmajer, T.; Perdih, A. Monocyclic 4-amino-6-(phenylamino)-1,3,5-triazines as inhibitors of human DNA topoisomerase II alpha. Bioorg. Med. Chem. Lett. 2014, 24 (24), 5762-5768.

(19) Cantero, G.; Campanella, C.; Mateos, S.; Cortes, F. Topoisomerase II inhibition and high yield of endoreduplication induced by the flavonoids luteolin and quercetin. Mutagenesis 2006, 21 (5), 321-325.

(20) Mittra, B.; Saha, D.; Chowdhury, A. R.; Pal, C.; Mandal, S.; Mukhopadhyay, S.; Bandyopadhyay, S.; Majumder, H. K. Luteolin, an abundant dietary component is a potent anti-leishmanial agent that acts by inducing topoisomerase II-mediated kinetoplast DNA cleavage leading to apoptosis. Mol. Med. 2000, 6 (6), 527-541.

(21) Constantinou, A.; Mehta, R.; Runyan, C.; Rao, K.; Vaughan, A.; Moon, R. Flavonoids as DNA topoisomerase antagonists and poisons - structure-activity-relationships. J. Nat. Prod. 1995, 58 (2), 217-225.

(22) Nitiss, J. L. DNA topoisomerase II and its growing repertoire of biological functions. Nat. Rev. Cancer 2009, 9 (5), 327-337.

(23) Pommier, Y.; Sung, Y. L.; Huang, S. Y. N.; Nitiss, J. L. Roles of eukaryotic topoisomerases in transcription, replication and genomic stability. Nat. Rev. Mol. Cell Biol. 2016, 17 (11), 703-721.

(24) Dalla Via, L.; Garcia-Argaez, A. N.; Adami, A.; Grancara, S.; Martinis, P.; Toninello, A.; Dell'Amico, D. B.; Labella, L.; Samaritani, S. Synthesis, antiproliferative and mitochondrial impairment activities of bis-alkyl-amino transplatinum complexes. Bioorg. Med. Chem. 2013, 21 (22), 6965-6972.

(25) Ormerod, M. G. The study of apoptotic cells by flow cytometry. Leukemia 1998, 12 (7), 1013-1025.

(26) Wlodkowic, D.; Skommer, J.; Darzynkiewicz, Z. Cytometry of apoptosis. Historical perspective and new advances. Exp. Oncol. 2012, $34(3), 255-262$. 